DOI: https://doi.org/10.24127/ajpm.v10i2.3523

\title{
ANALISIS KEMAMPUAN KOMUNIKASI MATEMATIS SISWA DALAM MEMECAHKAN MASALAH BERDASARKAN MOTIVASI BELAJAR SISWA
}

\author{
Marniati $^{*}$, Jahring ${ }^{2}$, Jumriani $^{3}$ \\ ${ }^{1 * 2,3}$ Pendidikan Matematika, Universitas Sembilanbelas November Kolaka, Indonesia \\ * Corresponding author. Jln. Pemuda No. 339 Kolaka, Sulawesi Tenggara, Indonesia. \\ E-mail: $\quad$ bungaitb@gmail.com ${ }^{\left.{ }^{*}\right)}$ \\ jahring.usn@gmail.com ${ }^{2)}$ \\ jrianimath@gmail.com $\left.{ }^{3}\right)$
}

Received 02 February 2021; Received in revised form 16 June 2021; Accepted 29 June 2021

\begin{abstract}
Abstrak
Kemampuan komunikasi matematis sangat diperlukan dalam pembelajaran matematika, bahkan merupakan salah satu kemampuan yang tergolong kemampuan berpikir tingkat tinggi atau high order thinking skills (HOTS). Oleh karena itu, penelitian ini bertujuan untuk mendeskripsikan kemampuan komunikasi matematis siswa ditinjau dari motivasi belajarnya. Jenis penelitian ini adalah penelitian kualitatif yang melibatkan 6 orang siswa kelas IX C SMP Negeri 1 Wolo. Data yang diperoleh dalam penelitian ini berupa: (1) data hasil angket motivasi belajar siswa; (2) data hasil tes kemampuan komunikasi matematis siswa; dan (3) data hasil wawancara dengan siswa. Instrumen pendukung yang digunakan adalah (1) angket motivasi belajar siswa; (2) soal tes kemampuan komunikasi matematis siswa; (3) pedoman wawancara; dan (4) alat perekan. Teknik pengumpulan data yang digunakan adalah triangulasi sumber, diantaranya: (1) angket motivasi belajar siswa; (2) tes kemampuan komunikasi matematis siswa; dan (3) wawancara. Teknik analisis data yang digunakan meliputi (1) reduksi data; (2) penyajian data; dan (3) penarikan kesimpulan. Hasil penelitian ini adalah kemampuan komunikasi matematis siswa dengan motivasi belajar tinggi berada pada kategori tinggi, kemampuan komunikasi matematis siswa denga motivasi belajar sedang berada pada kategori tinggi dan sedang, serta kemampuan komunikasi matematis siswa dengan motivasi belajar rendah berada pada kategori rendah.
\end{abstract}

Kata kunci: Kemampuan komunikasi matematis; motivasi belajar.

\begin{abstract}
Mathematical communication skills are very much needed in learning mathematics, in fact it is one of the abilities that are classified as high order thinking skills (HOTS). Therefore, This study aims to describe students' mathematical communication skills in terms of their learning motivation. This type of research is qualitative research involving 6 students of class IX C SMP Negeri 1 Wolo. The data obtained in this study were in the form of: (1) data from the questionnaire on student learning motivation; (2) data on students' mathematical communication skills test results; and (3) data from interviews with students. The supporting instruments used were (1) students' motivation questionnaire; (2) test questions on students' mathematical communication skills; (3) interview guidelines; and (4) press equipment. The data collection technique used was triangulation of sources, including: (1) a questionnaire on student learning motivation; (2) tests of students' mathematical communication skills; and (3) interviews. Data analysis techniques used include (1) data reduction; (data presentation; and (3) drawing conclusions. The results of this study are the mathematical communication skills of students with high learning motivation are in the high category, the students' mathematical communication skills with learning motivation are in the high and medium categories, and the mathematical communication skills of students with low learning motivation are in the low category.
\end{abstract}

Keywords: Learning motivation; mathematical communication skills. 
DOI: https://doi.org/10.24127/ajpm.v10i2.3523

\section{PENDAHULUAN}

Manusia dalam posisinya sebagai makhluk sosial tidak pernah lepas dari yang namanya komunikasi terhadap manusia lainnya, baik antar individu, individu dengan kelompok, maupun antar kelompok. Komunikasi pada dasarnya suatu interaksi yang dilakukan dengan orang lain dalam menyampaikan suatu informasi yang sifatnya multi arah. Oleh karena itu, dapat dikatakan bahwa proses belajar mengajar yang terjadi di dalam kelas merupakan bentuk kegiatan komunikasi karena antara guru dan siswa terlibat proses transformasi pesan, materi dan media pembelajaran, (Minrohmatillah, 2018; Tahir, 2021) .

Pada pembelajaran matematika, kemampuan komunikasi sangat diperlukan, bahkan menurut NCTM (Putri et al., 2018) menjadi salah satu dari lima kemampuan yang harus dimiliki siswa dalam pembelajaran matematika. Kemampuan komunikasi matematis merupakan kemampuan siswa untuk menyatakan ide-ide matematika baik secara lisan maupun tertulis, (Nasruddin \& Jahring, 2019). Kemampuan komunikasi juga dapat diartikan sebagai kemampuan memahami dan menerima gagasan atau ide matematika orang lain secara cermat, analisis, kritis, dan evaluatif untuk mempertajam pemahaman, (Babys, 2020). Lebih lanjut dikatakan oleh (K et al., 2021) bahwa kemampuan komunikasi matematis mencakup kecakapan siswa dalam dalam menyampaikan pemahamannya secara lisan dan tulisan dengan bahasa matematis.

Menurut (Nuraeni \& Luritawaty, 2016; Susanti et al., 2018), terdapat beberapa kegiatan atau kemampuan yang termasuk dalam bentuk kegiatan atau kemampuan komunikasi matematis, yaitu: (1) menyatakan suatu situasi, gambar, diagram, atau benda nyata ke dalam bahasa, simbol, idea, atau model matematik; (2) menjelaskan idea, situasi, dan relasi matematika secara lisan dan tulisan; (3) mendengarkan, berdiskusi, dan menulis tentang matematika; (4) membaca dengan pemahaman suatu representasi matematika tertulis; dan (5) mengungkapkan kembali suatu uraian datau paragraf matematika dalam bahasa sendiri. Oleh karena itu, indikator yang digunakan dalam mengukur kemampuan komunikasi matematis meliputi kemampuan (1) menyatakan situasi, benda nyata, dan gambar ke dalam ide matematika menggunakan bahasa sendiri; (2) menyatakan dan melukiskan ide-ide matematika ke dalam bentuk, gambar, benda nyata, atau grafik; dan (3) menyatakan peristiwa sehari-hari dalam bahasa atau simbol matematika untuk menyelesaikan masalah matematis.

Selain kemampuan komunikasi matematis, terdapat beberapa aspek afektif yang perlu dipertimbangkan dan turut memberikan sumbangsih terhadap keberhasilan belajar siswa, salah satunya adalah motivasi belajar siswa. Menurut (Abdi, 2018; Abdi \& Hasanuddin, 2018; Rigusti \& Pujiastuti, 2020), motivasi belajar adalah suatu daya, dorongan, dan atau kekuatan, baik yang berasal dari dalam diri siswa maupun yang berasal dari luar sebagai pendorong usaha dan pencapaian hasil belajar. Motivasi yang berasal dari dalam diri siswa disebut motivasi intrinsik dan timbul tanpa adanya campur tangan pihak luar, sedangkan motivasi yang berasal dari luar disebut motivasi ekstrinsik yang timbul karena adanya rangsangan dari luar dirinya atau lingkungannya, (Salahuddin, 2018). 
DOI: https://doi.org/10.24127/ajpm.v10i2.3523

Beberapa penelitian terkait kemampuan komunikasi matematis dan motivasi belajar, yaitu adanya hubungan positif antara motivasi belajar dan dengan kemampuan komunikasi matematis, (Abdi, 2018). Penelitian lain menunjukkan bahwa kemampuan komunikasi matematis dan motivasi belajar dapat ditingkatkan dengan pendekatan reciprocal teaching, (Putri et al., 2018). Berdasarkan analisisnya, beberapa penelitian terkait kemampuan komunikasi matematis juga telah dianalisis oleh beberapa peneliti sebelumnya, diantaranya analisis kemampuan komunikasi matematis siswa berdasarkan self concept, (Susanti et al., 2018), dan berdasarkan gender, (Babys, 2020).

Berdasarkan hasil wawancara dengan salah satu guru mata pelajaran matematika di SMP Negeri 1 Wolo didapatkan informasi bahwa siswa masih ragu-ragu dalam menyampaikan pendapat atau ide-ide matematis di dalam proses pembelajaran. Selain itu, ketika siswa diberikan soal cerita siswa kesulitan menyelesaikan soal dalam bahasa matematika atau bahasa sendiri dan juga siswa kesulitan dalam penggunaan simbol matematika yang sesuai. Hal tersebut menunjukkan bahwa kemampuan komunikasi matematis siswa masih rendah. Hal ini sejalan dengan hasil observasi, dimana siswa tidak memahami matematika dengan jelas, siswa merasa gelisah ketika belajar matematika, siswa masih pasif dan kurang bersemangat di dalam proses pembelajaran matematika, ketika diberi soal siswa tidak berusaha untuk menemukan solusinya, pada saat diberi tugas matematika siswa mengeluh karena banyak tugas pelajaran yang lain, dan juga siswa enggan untuk bertanya ketika ada yang tidak dimengerti.
Beberapa masalah yang teridentifikasi di lapangan, membuat peneliti tertarik menganalisis kemampuan komunikasi matematis yang merupakan indikasi awal dari permasalahan yang ada. Beberapa gejala-gejala yang ditunjukkan siswa merujuk pada aspek motivasi belajar. Dengan demikian analisis kemampuan komunikasi matematis dalam penelitian ini ditinjau dari motivasi belajar siswa. Hasil analisis ini, diharapkan dapat memberikan informasi awal bagi guru dan tenaga pendidik lainnya untuk tetap mempertimbangkan aspek psikologis atau afektif dalam pembelajaran matematika.

Adapun perbedaan penelitian ini adalah kemampuan komunikasi matematis dianalisis berdasarkan motivasi belajar siswa. Terdapat pengkategorian kemampuan komunikasi matematis dan motivasi belajar. Dari hasil pengkategorian ini kemudian diklasifikasikan berdasarkan kategori yang sama, baik itu kemampuan komunikasi matematis, maupun motivasi belajar. Oleh karena itu, penelitian ini bertujuan untuk menganalisis dan mengeksplorasi kemampuan komunikasi matematis siswa berdasarkan motivasi belajarnya.

\section{METODE PENELITIAN}

Jenis penelitian yang dilakukan adalah deskriptif. Penelitian ini dilaksanakan di kelas IXC SMP Negeri 1 Wolo yang beralamatkan di Desa Wolo, Kecamatan Wolo, Kabupaten Kolaka, Sulawesi Tenggara. Subjek penelitian sebanyak 6 siswa yang terdiri dari 2 siswa dengan motivasi belajar tinggi, 2 siswa dengan motivasi belajar sedang dan 2 siswa dengan motivasi belajar rendah.

Data yang diperoleh berupa (1) data hasil tes kemampuan komunikasi 
matematis; (2) data hasil angket motivasi belajar; dan (3) data hasil wawancara. Instrumen penelitian yang digunakan diantaranya (1) soal tes kemampuan komunikasi matematis; (2) angket motivasi belajar; (3) panduan wawancara; dan (4) alat perekam. Teknik pengumpulan data yang digunakan, yaitu (1) tes kemampuan komunikasi matematis; pada teknik ini siswa diberikan serangkaian soal yang memuat indikator kemampuan komunikasi matematis, yang selanjutnya hasil pengerjaan siswa dianalisis sebagai data kemampuan komunikasi matematis; (2) non-tes (angket motivasi belajar); pada teknik ini, subjek diberikan serangkaian pernyataan terkait kondisi yang sesuai atau tidak sesuai dengan kondisi subjek. Hasilnya kemudian dianalisis sebagai data tentang motivasi belajar siswa; dan (3) wawancara, pada teknik ini diberikan serangkaian pertanyaan secara lisan kepada subjek terkait kemampuan komunikasi matematis sebagai tindak lanjut dari hasil tes kemampuan komunikasi matematis. Hal ini dilakukan untuk mengkonfirmasi hasil tes siswa serta memperoleh keterangan lebih lanjut terkait komunikasi matematis.

Teknik analisis data yang digunakan adalah teknik data kualitatif, meliputi: (1) Reduksi Data, yaitu mengoreksi hasil tes kemampuan komunikasi matematis dan angket motivasi belajar dan mengkategorikan sesuai aturan pengkategorian (Tabel 2 dan Tabel 3), yang selanjutnya dikelompokkan antara kemampuan komunikasi matematis dan motivasi belajar, dan tahap akhir melakukan wawancara terhadap subjek yang dipilih atas hasil pengkategorian dan pengelompokkan; (2) Penyajian Data merupakan tindak lanjut dari reduksi data. Data yang sudah direduksi selanjutnya disajikan dalam bentuk naratif; dan (3) Pengambilan Kesimpulan, merupakan tahap akhir dalam melakukan analisis data. Penarikan kesimpulan dilakukan dengan melihat hasil kerja siswa dan hasil wawancara untuk menentukan gambaran kemampuan komunikasi matematis yang dimiliki oleh siswa berdasarkan motivasi belajarnya.

Tabel 1.Pengkategorian motivasi belajar siswa

\begin{tabular}{cc}
\hline Interval Nilai & Kategori \\
\hline $80 \leq N \leq 100$ & Tinggi \\
$60 \leq N<80$ & Sedang \\
$0 \leq N<60$ & Rendah \\
\hline
\end{tabular}

Tabel 2.Pengkategorian kemampuan komunikasi matematis

\begin{tabular}{cc}
\hline Interval Nilai & Kategori \\
\hline $66<P \leq 100$ & Tinggi \\
$33<P \leq 66$ & Sedang \\
$P \leq 33$ & Rendah \\
\hline
\end{tabular}

\section{HASIL DAN PEMBAHASAN}

Kemampuan Komunikasi Matematis Siswa yang Memiliki Motivasi Tinggi

Berdasarkan hasil angket motivasi belajar dan tes kemampuan komunikasi matematis siswa diperoleh kelompok siswa yang masuk dalam kategori motivasi belajar tinggi. Oleh karena itu, terpilih 2 subjek, yaitu $\mathrm{S} 1$ dan $\mathrm{S} 2$. Berikut hasil analisis untuk masingmasing subjek penelitian.

\section{Subjek $\mathrm{S} 1$}

Subjek S1 berhasil menyelesaikan tiga soal. Hasil tes kemampuan komunikasi matematis subjek S1 pada soal nomor 1 sampai sampai nomor 3 disajikan pada Gambar 1 sampai Gambar 3. 
DOI: https://doi.org/10.24127/ajpm.v10i2.3523

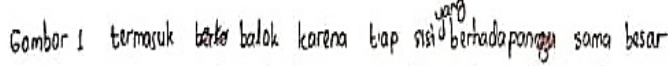

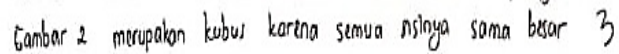

Gambar 1. Tes kemampuan komunikasi matematis oleh subjek S1 pada nomor 1

permuksan kutus $=6 \mathrm{~s}^{2}$

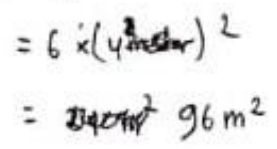

Gambar 2. Tes kemampuan komunikasi matematis oleh subjek S1 pada nomor 2

$$
\begin{aligned}
\text { L. pirmukaan balok } & =2 \times(p l+p t+l t) \\
& =2 \times((30 \times 10)+(30 \times 20)+(10 \times 20)) \\
& =2(300+600+200) \\
& =2(1.100) \\
& =2.200 \mathrm{~cm}^{2}
\end{aligned}
$$

Gambar 3. Tes kemampuan komunikasi matematis oleh subjek S1 pada nomor 3

Subjek S1 mampu menyelesaikan setiap soal dengan benar, baik pada indikator menyatakan situasi, benda nyata dan gambar ke dalam ide matematika menggunakan bahasa sendiri, menyatakan dan melukiskan ide-ide matematika ke dalam bentuk, gambar, benda nyata, atau grafik maupun pada indikator menyatakan peristiwa sehari-hari dalam bahasa atau simbol matematika untuk menyelesaikan masalah matematis. Hal ini diperkuat dengan hasil wawancara subjek S1 yang mampu menjelaskan kembali jawaban dari soal secara benar serta memahami alur pengerjaan soal.

\section{Subjek $\mathrm{S} 2$}

Subjek S2 hanya dapat mengerjakan dua soal. Hasil tes kemampuan komunikasi matematis subjek S2 pada soal nomor 1 pada Gambar 4 dan nomor 3 pada Gambar 5.
Subjek S2 benar pada indikator menyatakan situasi, benda nyata dan gambar ke dalam ide matematika menggunakan bahasa sendiri, dan indikator menyatakan dan melukiskan ide-ide matematika ke dalam bentuk, gambar, benda nyata, atau grafik, sedangkan pada indikator menyatakan peristiwa sehari-hari dalam bahasa atau simbol matematika untuk menyelesaikan masalah matematis subjek S2 tidak memberikan jawaban sama sekali. Namun berdasarkan perhitungan nilainya masih berada pada rentang kategori tinggi. Hal ini diperkuat dengan hasil wawancara subjek S2 yang menyatakan bahwa alasan tidak terjawabnya soal nomor 2 karena subjek S2 memang sama sekali tidak mengetahui cara penyelesaiannya.

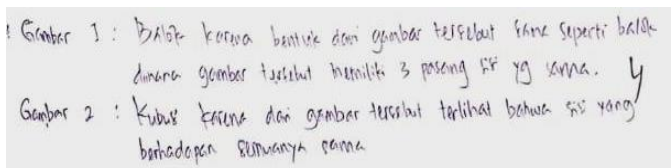

Gambar 4. Tes kemampuan komunikasi matematis oleh subjek S2 pada nomor 1

$$
\begin{aligned}
\text { Luas permukatan } & =2 \times(p 1+p t+1 t) \\
& =2 \times(30 \times 10+30 \times 20+10 \times 20) \\
& =2 \times(300+600+200) \quad y \\
& =2 \times 1.1000 \\
& =2.200 \mathrm{~cm}^{2}
\end{aligned}
$$

Gambar 5. Tes kemampuan komunikasi matematis oleh subjek S2 pada nomor 3

Kemampuan komunikasi matematis siswa pada setiap indikator menunjukkan bahwa pada indikator pertama S1 lebih rendah dibandingkan dengan S2, namun lebih tinggi pada indikator ketiga. Sedangkan pada indikator kedua, baik S1 maupun S2 sama. Perbandingan kemampuan komunikasi matematis siswa pada S1 dan S2 disajikan dalam bentuk diagram pada Gambar 6. 
DOI: https://doi.org/10.24127/ajpm.v10i2.3523

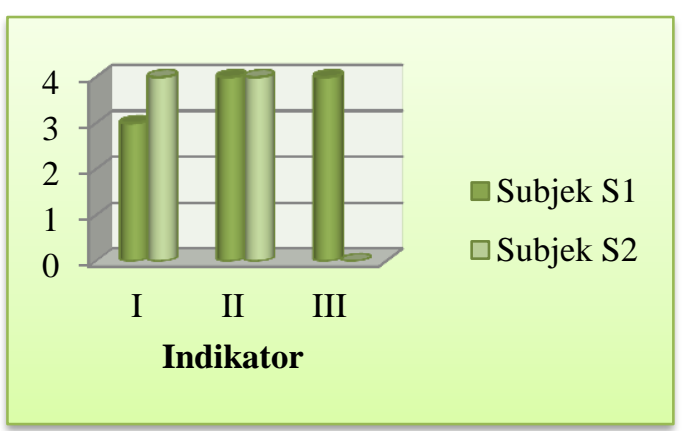

Gambar 6. Kemampuan komunikasi matematis siswa dengan motivasi belajar tinggi

Berdasarkan hasil kemampuan komunikasi matematis siswa dengan motivasi belajar tinggi dapat disimpulkan bahwa kemampuan komunikasi matematis siswa berada pada kategori tinggi karena baik subjek S1 maupun subjek S2 dapat menjawab soal dengan baik yang mewakili setiap indikator kemampuan komunikasi matematis, meskipun subjek S2 tidak dapat menjawab soal yang mewakili indikator menyatakan peristiwa seharihari dalam bahasa atau simbol matematika untuk menyelesaikan masalah matematis, namun berdasarkan perhitungan nilai rentang kemampuan komunikasi matematis, masih berada dalam kategori tinggi. Hal ini merupakan imbas atau pengaruh terhadap motivasi yang tinggi sehingga kemampuan komunikasi matematisnya pun juga tinggi.

Hasil yang diperoleh oleh S1 dan S2 sejalan dengan hasil penelitian (Nurmantoro, 2017) bahwa terdapat pengaruh langsung motivasi belajar terhadap kemampuan komunikasi matematis. Selain itu, terdapat hubungan positif antara motivasi belajar dan kemampuan komunikasi matematis siswa, (Abdi, 2018; Wulandari et al., 2018).
Kemampuan Komunikasi Matematis Siswa yang Memiliki Motivasi Sedang

Berdasarkan hasil angket motivasi belajar dan tes kemampuan komunikasi matematis siswa diperoleh kelompok siswa yang masuk dalam kategori motivasi belajar sedang. Oleh karena itu, terpilih 2 subjek, yaitu S3 dan S4. Berikut hasil analisis untuk masingmasing subjek penelitian.

\section{Subjek S3}

Subjek S3 berhasil menyelesaikan tiga soal. Hasil tes kemampuan komunikasi matematis subjek S3 pada soal nomor 1 sampai 3 (Gambar 7 sampai 9).

\section{gambar 1 adaloh balok karena memiliti 3 pasang sisi
Yang berbeda gambar 2 adalah kubus barna semue sisinya sama. I}

Gambar 7. Tes kemampuan komunikasi matematis oleh subjek S3 pada nomor 1

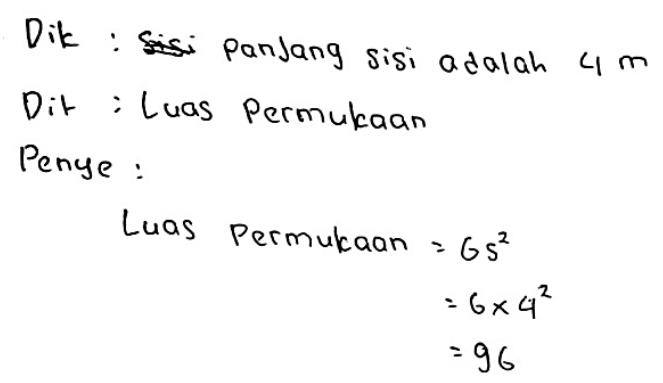

Gambar 8. Tes kemampuan komunikasi matematis oleh subjek S3 pada nomor 2

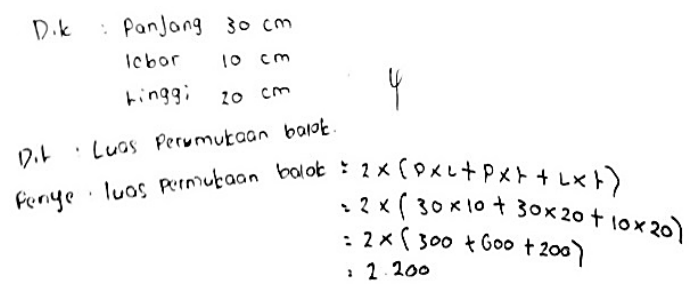

Gambar 9. tes kemampuan komunikasi matematis oleh subjek S3 pada nomor 3 
Subjek S3 mampu menyelesaikan setiap soal, baik pada indikator menyatakan situasi, benda nyata dan gambar ke dalam ide matematika menggunakan bahasa sendiri, menyatakan dan melukiskan ide-ide matematika ke dalam bentuk, gambar, benda nyata, atau grafik maupun pada indikator menyatakan peristiwa seharihari dalam bahasa atau simbol matematika untuk menyelesaikan masalah matematis. Walaupun skor yang diperoleh belum maksimal pada indikator II dan III. Hal ini diperkuat dengan hasil wawancara subjek S3 yang menyatakan bahwa tidak ingat untuk menuliskan jawaban dengan lengkap beserta satuan yang dipersyaratkan oleh soal.

\section{Subjek S4}

Subjek S4 hanya dapat menjawab dua soal. Hasil tes kemampuan komunikasi matematis subjek S4 pada soal nomor 1 pada Gambar 10 dan nomor 3 pada Gambar 11 .

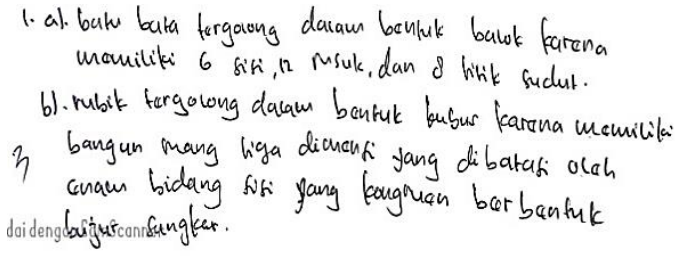

Gambar 10. Tes kemampuan komunikasi matematis oleh subjek S4 pada nomor 1

$$
\begin{aligned}
\text { 3.1.p.baluk } & =2 \times(p 1+p t+1 t) \\
& =2 \times((30 \times 10)+(30 \times 20)+(10 \times 20)) \\
& =2 \times(300+600+200) \\
& : 2 \times 1.100 \\
& : 2.200 \mathrm{~cm}^{2}
\end{aligned}
$$

Gambar 11. Tes kemampuan komunikasi matematis oleh subjek S4 pada nomor 3
Berdasarkan hasil tes tertulis kemampuan komunikasi matematis, subjek S4 memiliki kemampuan komunikasi matematis sedang karena subjek S4 hanya memperoleh skor maksimal pada soal nomor 3 yang mewakili indikator menyatakan dan melukiskan ide-ide matematika ke dalam bentuk, gambar, benda nyata, atau grafik, sedangkan pada soal nomor 1 skornya belum maksimal yang mewakili indikator menyatakan situasi, benda nyata dan gambar ke dalam ide matematika menggunakan bahasa sendiri, dan pada indikator menyatakan peristiwa sehari-hari dalam bahasa atau simbol matematika untuk menyelesaikan masalah matematis, subjek S4 tidak menjawab sama sekali. Hal ini diperkuat dengan hasil wawancara subjek S4 yang menyatakan bahwa tidak tahu sama sekali solusi dari soal nomor 2 serta masih sedikit bingung untuk membedakan definisi dan sifat kubus serta balok pada soal nomor 1 .

Hasil analisis kemampuan komunikasi matematis pada setiap indikator menunjukkan bahwa pada indikator pertama dan ketiga, S3 lebih tinggi dibandingkan dengan S4, namun lebih rendah pada indikator kedua. Perbandingan kemampuan komunikasi matematis S3 dan S4 disajikan dalam bentuk diagram pada Gambar 12.

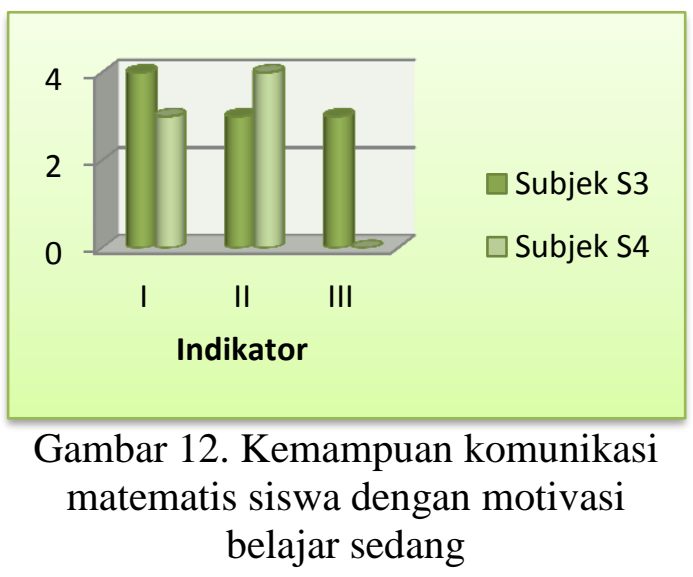


DOI: https://doi.org/10.24127/ajpm.v10i2.3523

Berdasarkan hasil kemampuan komunikasi matematis siswa dengan motivasi belajar sedang dapat disimpulkan bahwa kemampuan komunikasi matematis siswa bervariasi, terdapat kemampuan komunikasi matematis siswa yang tinggi juga terdapat kemampuan komunikasi matematis siswa sedang. Hal ini disebabkan karena adanya pengaruh positif antara motivasi belajar dan kemampuan komunikasi matematis, sehingga dengan motivasi belajar pada kategori sedang dapat menyebabkan kemampuan komunikasi matematis menjadi tinggi, dilain pihak juga dapat menyebabkan kemampuan komunikasi matematis siswa pada kategori sedang. Artinya bahwa motivasi belajar punya kontribusi yang signifikan dalam pengembangan atau peningkatan kemampuan komunikasi matematis siswa, (Abdi \& Hasanuddin, 2018).

\section{Kemampuan Komunikasi Matematis Siswa yang Memiliki Motivasi Rendah}

Berdasarkan hasil angket motivasi belajar dan tes kemampuan komunikasi matematis siswa diperoleh kelompok siswa yang masuk dalam kategori motivasi belajar rendah. Oleh karena itu, terpilih 2 subjek, yaitu S5 dan S6. Berikut hasil analisis untuk masingmasing subjek penelitian.

\section{Subjek S5}

Subjek S5 menjawab tiga soal. Hasil tes kemampuan komunikasi matematis S5 pada soal nomor 1 sampai 3 (Gambar 13 sampai 15).

\section{Gambar I balok Gambar 2 kubus.}

Gambar 13. Tes kemampuan komunikasi matematis oleh subjek S5 pada nomor 1

\section{was permukann balok $60 \mathrm{~cm}$}

Gambar 14. Tes kemampuan komunikasi matematis oleh subjek S5 pada nomor 2

$$
4 \times 4=16 \mathrm{~m}
$$

Gambar 15. Tes kemampuan komunikasi matematis oleh subjek S5 pada nomor 3

Subjek S5 hanya memperoleh nilai 1 pada setiap soal untuk semua indikator yang mewakili kemampuan komunikasi matematis siswa. Hal ini diperkuat dengan hasil wawancara bahwa S5 mengerti soal nomor 1 merupakan gambar balok dan kubus, dan tahu yang ditanyakan adalah definisnya, namun tidak bisa memberikan jawaban sesuai permintaan soal. Begitu juga dengan soal nomor 2 dan nomor 3 .

\section{Subjek S6}

Subjek S6 hanya menjawab 2 soal, dan jawaban yang diberikan tidak tepat. Hasil tes kemampuan komunikasi matematis S6 untuk soal nomor 1 pada Gambar 16 dan nomor 3 pada Gambar 17.

$$
\begin{aligned}
& \text { 1. gambar } 1 \text { batu bata } \\
& \text { gambar } 2 \text { mainanRubik }
\end{aligned}
$$

Gambar 16. Tes kemampuan komunikasi matematis oleh subjek S6 pada nomor 1

\section{Luasinya adalah luas balok}

Gambar 17. Tes kemampuan komunikasi matematis oleh subjek S6 pada nomor 3 
Subjek S6 keliru dalam menjawab soal nomor 1 yang mewakili indikator menyatakan situasi, benda nyata dan gambar ke dalam ide matematika menggunakan bahasa sendiri, begitu pula pada indikator menyatakan dan melukiskan ide-ide matematika ke dalam bentuk, gambar, benda nyata, atau grafik, S6 hanya memperoleh skor 1 dan pada indikator menyatakan peristiwa sehari-hari, dalam bahasa atau simbol matematika untuk menyelesaikan masalah matematis, subjek S6 tidak menjawab sama sekali.

Hasil Kemampuan komunikasi matematis siswa pada pada setiap indikator menunjukkan bahwa pada indikator pertama dan kedua, subjek S5 dan subjek S6 sama, namun subjek S5 lebih tinggi pada indikator ketiga. Perbandingan kemampuan komunikasi matematis siswa pada subjek S5 dan subjek S6 disajikan dalam bentuk diagram pada Gambar 18.

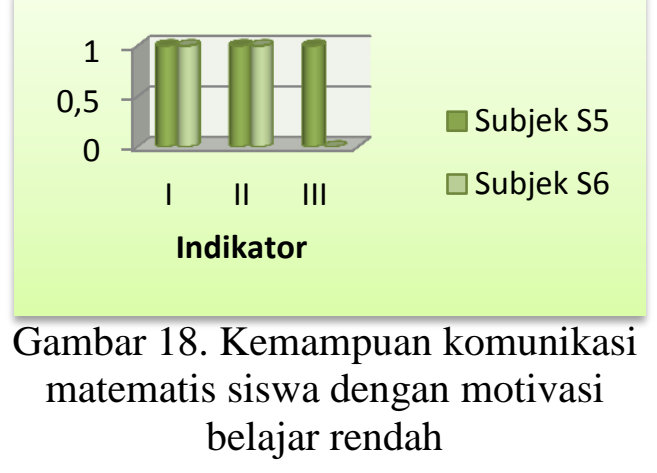

Berdasarkan hasil analisis dapat disimpulkan bahwa siswa dengan motivasi belajar rendah maka kemampuan komunikasinya juga rendah. Hal ini tidak dapat dipungkiri bahwa motivasi belajar dan kemampuan komunikasi matematis memiliki hubungan positif, artinya jika motivasi belajar rendah maka kemampuan motivasi rendah, dan sebaliknya, (Abdi, 2018).
Berdasarkan hasil yang telah diperoleh, bahwa kelompok siswa dengan motivasi belajar yang tinggi dan sedang mempunyai kemampuan komunikasi matematis yang tinggi. Sedangkan kelompok siswa dengan motivasi belajar rendah, memiliki kemampuan komunikasi matematis rendah. Hal ini disebabkan oleh motivasi belajar siswa yang tinggi akan meningkatkan kemampuan komunikasi matematis siswa. Hal ini sejalan dengan penelitian (Nurmantoro, 2017; Robiah et al., 2019), bahwa terdapat pengaruh langsung, positif dan signifikan motivasi belajar siswa terhadap kemampuan komunikasi matematis. Oleh karena itu, motivasi belajar menjadi salah satu faktor yang tidak boleh diabaikan dalam hal peningkatan kemampuan komunikasi matematis. Dengan demikian, dalam upaya peningkatan kemampuan komunikasi matematis siswa pada khususnya, dan hasil belajar matematika siswa pada umumnya. Maka motivasi belajar menjadi salah satu faktor yang perlu diperhatikan. Tingginya motivasi belajar yang dimiliki oleh siswa membuat dirinya semakin bersemangat untuk meningkatkan kemampuan dirinya. Hal ini disebabkan karena, pada dasarnya motivasi belajar adalah dorongan yang berasal dari dalam diri siswa untuk mencapai sesuatu yang diinginkannya. Hal ini sejalan dengan pendapat (Masni, 2015) bahwa siswa mempunyai dorongan dari dalam dirinya untuk melakukan kegiatan belajar yang disebut motivasi belajar.

\section{KESIMPULAN DAN SARAN}

Berdasarkan hasil penelitian, dapat disimpulkan bahwa kemampuan komunikasi matematis siswa dengan motivasi belajar tinggi berada pada kategori tinggi dan memenuhi semua 
DOI: https://doi.org/10.24127/ajpm.v10i2.3523

indikator kemampuan komunikasi matematis, Selanjutnya, kemampuan komunikasi matematis siswa dengan motivasi belajar sedang berada pada kategori tinggi dan sedang, serta kemampuan komunikasi matematis siswa dengan motivasi belajar rendah berada pada kategori rendah. Serta memenuhi indikator kemampuan komunikasi matematis.

Saran dalam penelitian ini adalah bagi peneliti selanjutnya dapat mengkaji terkait hubungan antara motivasi belajar dan kemampuan komunikasi matematis khususnya dalam pemecahan masalah matematis.

\section{DAFTAR PUSTAKA}

Abdi, M. (2018). Hubungan Motivasi Belajar dengan Kemampuan Komunikasi Matematis Siswa. Jurnal Pendidikan Tambusai, 2(3), 1687-1692. https://doi.org/10.31004/jptam.v2i 3.157

Abdi, M., \& Hasanuddin, H. (2018). Pengaruh Model Pembelajaran Think Pair Share dan Motivasi Belajar terhadap Kemampuan Komunikasi Matematis Siswa Sekolah Menengah Pertama. JURING (Journal for Research in Mathematics Learning), 1(2), 99110.

https://doi.org/10.24014/juring.v1i 2.4778

Babys, U. (2020). Analisis Kemampuan Komunikasi Matematika Siswa Ditinjau dari Gender. ANARGYA: Jurnal Ilmiah Pendidikan Matematika, 3(1), 25-29. https://doi.org/10.24176/anargya.v 3i1.4771

K, I., Jahring, \& Subawo, M. (2021). Analisis Kemampuan Komunikasi Matematis Siswa Ditinjau Dari Gaya Belajar. Square: Journal of
Mathematics and Mathematics Education, 3(1), 56-65. https://doi.org/10.21580/square.20 21.3.1.7704

Masni, H. (2015). Strategi Meningkatkan Motivasi Belajar Mahasiswa. Dikdaya, 5(1), 34-45. https://doi.org/10.33087/dikdaya.v $5 \mathrm{i} 1.64$

Minrohmatillah, N. (2018). Analisis Kemampuan Komunikasi Matematis Siswa Ditinjau Dari Gaya Kognitif Reflektif Impulsif. JP2M: Jurnal Pendidikan Dan Pembelajaran Matematika, 4(2), 68-75.

https://doi.org/10.29100/jp2m.v4i 2.957

Nasruddin, N., \& Jahring, J. (2019). Efektivitas Penerapan Model Pembelajaran Reciprocal Teaching dalam Meningkatkan Kemampuan Komunikasi Matematis Siswa. SAINTIFIK, 5(1), 27-35. https://doi.org/10.31605/saintifik. v5i1.195

Nuraeni, R., \& Luritawaty, I. P. (2016). Mengembangkan Kemampuan Komunikasi Matematik Siswa melalui Strategi Think Talk Write. Mosharafa: Jurnal Pendidikan Matematika, 5(2), 101-112. https://doi.org/10.31980/mosharaf a.v5i 2.265

Nurmantoro, M. A. (2017). Pengaruh Kemampuan Awal, Kecerdasan Emosi dan Motivasi Belajar Terhadap Kemampuan Komunikasi Matematis Siswa. Prosiding Diskusi Panel Pendidikan "Menjadi Guru Pembelajar," April, 1-11. https://journal.lppmunindra.ac.id/i ndex.php/repository/article/view/1 659 
Putri, A. A., Rindawanti, W., Hutajulu, M., \& Heris, H. (2018). Meningkatkan Kemampuan Komunikasi dan Motivasi Belajar Matematis Siswa SMP dengan Menggunakan Pendekatan Reciprocal Teaching. JES-MAT (Jurnal Edukasi Dan Sains Matematika), 4(2), 105-120. https://doi.org/10.25134/jesmat.v4i2.1453

Rigusti, W., \& Pujiastuti, H. (2020). Analisis Kemampuan Pemecahan Masalah Ditinjau Dari Motivasi Belajar Matematika Siswa. Prima: Jurnal Pendidikan Matematika, 4(1), 1-10. https://doi.org/10.31000/prima.v4i 1.2079

Robiah, S., Rohaeti, E. E., \& Senjayawati, E. (2019). Analisis Kemampuan Komunikasi Matematis Siswa Berdasarkan Minat Belajar Matematis Siswa Smk Negeri 1 Cihampelas. Journal On Education, 01(02), 365-371.

https://doi.org/10.31004/joe.v1i2. 76

Salahuddin, I. (2018). Pengaruh Kemampuan Awal, Kepercayaan Diri, Motivasi Belajar Terhadap Kemampuan Komunikasi Matematis Siswa. Proximal Jurnal Penelitian Matematika Dan Pendidikan Matematika, 1(2), 144-155.

Susanti, M., Kurnia, H. I., Nurfauziah, P., \& Hendriana, H. (2018). Analisis Kemampuan Komunikasi Matematis Siswa SMP Di Tinjau Dari Self-Concept. SOSIOHUMANIORA: Jurnal Ilmiah Ilmu Sosial Dan Humaniora, 4(2), 91-101. https://doi.org/10.30738/sosio.v4i 2.2751
Tahir, T. (2021). The Effect of Learning Styles on Students ' Mathematical Communication Ability. Journal of Medives: Journal of Mathematics Education IKIP Veteran Semarang, 5(1), 13-21. https://doi.org/10.31331/medivesv eteran.v5i1.1378

Wulandari, A. E., Azhar, E., \& Jusra, H. (2018). Hubungan Antara Motivasi Belajar Terhadap Kemampuan Pemecahan Masalah Matematis Siswa pada Kelas VII. Seminar Nasional Pendidikan Matematika, 01, 397-405. 